\title{
Extradition Process in Transnational Criminal Act to Find The Perpetrators
}

\author{
MUHAMMAD RAKHMAT \\ Faculty of Law, Majalengka University \\ email: hadhyana@yahoo.com
}

\begin{abstract}
In some researches, it is elaborated that in the process of extradition, Mutual Legal Assistance (MLA), Good Mutual Relation which conducted between governments are represented by central authority from each state, whilst the process of handing-over is conducted by the police (NCB- Interpol) of each state. Those for means are conducted in four steps, namely, pre-request, procedure in the requesting state, a procedure in the requested state and post-request. In practice, those four steps are influenced by ten factors: the difference in legal system and legal politics, the existence of agreement between the requesting state and the requested state, clauses and the qualification of the clauses in the agreement of extradition or MLA, formulation of extradition and MLA in international convention, formulation of extradition and MLA in the requested state, relationship of the requesting and the requested states, bargaining position of a state, facility and infrastructure, law enforcer means and law awareness of law subject.
\end{abstract}

Keywords: criminal law, extradition projection, mutual legal assistance

\section{Introduction}

Within the field of international criminal law, the name of transnational crimes would affect two or more countries, as it covers the involvement of various nationality of perpetrators and victims, as well as the locus delicate in several countries and the scene of the crime and infrastructure which are transnational in nature (Atmasasmita, 1998: 27). For example, we see a variety of cases such as cyber crime, money laundering, corruption, trafficking, and so forth. The next type of criminal offense is an international crime. The elements that accompany international crime are almost the same as transnational crimes. The difference is that international crime has broad impact on the interests of the international community or the whole country in the world, so it is often said that international crime is the enemy of mankind (Hostis Humanist Generis) (Atmasasita Ibid,: 48), for example genocide, crimes against humanity, war crimes, and aggression.

This international crime has a global impact. Therefore, all countries in the world have the jurisdiction to arrest, detain, prosecute and trial the perpetrators. It is based on the principal au dedere au Judicare of Bassiouni's and the principle of au dedere au punere of Hugo Grotius'.

According to the researchers, urgent issues to be observed today in the case of criminal offenses, are criminal national offenses, transnational crimes, as well as international crime, and all about the perpetrators, evidence, and asset of the proceeds of crime in the territory of another country. At glance, the type of the offenses that may lead to the perpetrators, evidence, and asset proceeds of crime in the territory of another country is a crime, transnational or international crime, but when it examined further, criminal acts nationwide can lead to the perpetrators, evidence, and asset proceeds crime to be in the territory of another country. An example, of such case is the national criminal who offender fled to other countries and was in number of countries for long periods of time in order to avoid criminal charges from the state which has jurisdiction upon it (Parthiana, 2006: 136).

Received: May 24, 2016, Revision: November 15, 2016, Accepted: December 19, 2016

Print ISSN: 0215-8175; Online ISSN: 2303-2499. Copyright@2016. Published by Pusat Penerbitan Universitas (P2U) LPPM Unisba Accredited by DIKTI. SK Kemendikbud, No.040/P/2014, valid 18-02-2014 until 18-02-2019 
Another thing is the occurrence of transnational criminal or international crime where the perpetrator of a criminal act on the territory of another state in which generally the offender and the evidence is in the country where locus delicti occurs, or criminal offenses assets resulting from criminal acts have been placed (placement) or transferred (layering) into the territory of other countries, for example in the case of Money Laundering Act.

In that regard, the state that has jurisdiction to prosecute the offender faces problems in processing legal culprit, ranging from inspection by law enforcement officials, such as police, prosecutors, and the court since the offender is in the territory of another country (Parthiana, 2006). This applies to evidence in the territory of another country, in addition that the evidence is very important in the process of the trial that will become the basis for the judge to decide guilt or innocence of the perpetrator of a criminal act. It is no less important that the assets of the proceeds of crime in the territory of another country, which usually the property, does not belong to the perpetrator but it is owned by other parties. In the case of corruption, for example, such property is owned by the state, which if left alone, it would harm or destabilize the country's economy, which indirectly inhibits the prosperity of a country.

Indonesia is one of the countries facing such problems. Of the many cases, problems concerning evidence located in the territory of another state which attracts public attention is the case of Oki. Oki was murdered in the United States, in this case the tool of the proof is in the United States. Whilst the problem of actors and assets of proceeds of crime in the territory of another country that became public spotlight occurred in the corruption Bank Indonesia Liquidity Assistance (BLBI), which after committing the corruption, the perpetrators fled to another country and smuggled its assets resulting from criminal acts.

Based on the data obtained, BLBI is schemes of aid (loans) provided by Bank Indonesia to banks which experiencing liquidity problems, for example in the event of a financial crisis in 1998. At that time in order to recover monetary instability of the banking crisis of 1998. In December 1998 Bank Indonesia BLBI distributed Rp $147,700,000,000,000$, - (one hundred and forty-seven trillion seven hundred billion rupiah) to 48 (forty-eight) bank. It is unfortunate that government assistance recipients were responded negatively by BLBI, namely BLBI funds disbursed by Bank Indonesia that have been distorted, it is known from the audit that there has been a deviation indication of BLBI for Rp 138,000,000,000,000, - (one hundred and thirty-eight trillion). Another bitter truth is that when the perpetrators are prosecuted, they (the recipients BLBI) fled to other countries by bringing a number of assets that have been distorted earlier.

When looking at that fact, it is ironic. In the midst of a crisis that nearly brought down the economy of Indonesia which consequently increase the level of unemployment, poverty, crime, and so forth, they (recipients of BLBI) did the massive corruption, not just the millions or hundreds of millions, but already in level of trillions of rupiahs. If the funds were not diverted, they can be used to improve the welfare of society widespread.

In such case, it means that there is the need for cooperation between countries that have jurisdiction in the country where the perpetrator, evidence or assets of the proceeds of crime exist. In this regard, according to Romli Atmasasmita, in case of the perpetrators and evidence or assets of the proceeds of crime in the territory of another country, the government can use cooperation that is considered as established enough because it has been acknowledged by international law and practice, including cooperation through three channels, namely; diplomatic channels, the extradition treaty and mutual legal assistance in criminal matters or better known as the Mutual Legal Assistance In Criminal Matters (MLA); The channel of center of power, namely between the justice ministers of the countries concerned in the form of good relations with the principle of reciprocity, as well as pathways Interpol, which is among the state police of the police force of other countries, where the "Handing Over" is often done in cases of suspected or convicted of narcotics (Atmasasmita, Op cit: 34)."

Based on the three channels, it can be concluded that there are four (4) means for obtaining the perpetrator and evidence or assets that are the proceeds of crime in the territory of another country, namely, extradition, MLA, good mutual relations and handing-over. The researchers used the term Handing-Over instead of Interpol because in practice means of consignment is not called Interpol but Handing-Over and Interpol is the 
executor of the Handing-Over.

The implementation of the means "have been ruled out", for example in the case of Adolf Eichmann in 1963. Adolf Eichmann was a German Nazi leader who was instrumental in the extermination of Jews in Europe during World War II (1939-1945). After the end of World War II with the defeat of the axis (Germany, Italy, and Japan), they started to arrest people accused as perpetrators of genocide, crimes against humanity, war crimes or aggression, one of which was Adolf Eichmann. To avoid the arrest, Adolf Eichmann escaped to Argentina, where he lives safely over ten years. When Israeli secret service was in charge of hunting down the war criminals in World War II on trial by Israel, Adolf Eichmann was found in Argentina. Unfortunately, Argentina and Israel have not been tied to an Extradition Treaty, which would serve as the basis for the extradition of the perpetrator from Argentina to Israel. To be able to take him to Israel, there was preparations and planning to kidnap him, and eventually Adolf Eichmann was captured and taken out of Argentina to Israel with a very confidential manner.

In such cases, according to researchers, if Israel and Argentina have no Extradition Treaty, it is inappropriate to use abduction, because it adds to human rights violation, and also considered as an act of intervention by the Argentine authorities. So it could have used other means such as good mutual relationships or handing-over.

Based on the explanation above it can be concluded that the implementation of the extradition, MLA, good relations and handingover is not in line with consideration, but it has a myriad of problems, so it needs to be questioned about the existence of extradition, MLA, good relations and handing-over in the future to obtain offender, evidence or assets of the proceeds of crime in the territory of another country.

\section{The Implementation of Extradition, MLA and others}

Extradition, MLA, good mutual relations and handing-over can be used as tools, means to obtain the perpetrators and evidence or assets resulting from criminal acts in the territory of other countries, so that the perpetrators or evidence of criminal acts in the territory of another country can be prosecuted by Indonesian criminal law in Indonesia, while for assets resulting from criminal acts, when they are switched to the hands of Indonesia, then they can be returned to the owner. Extradition, MLA, good relations and handingover are necessary in order to enforce the national criminal law of Indonesia indirectly aimed at achieving the state goals.

Based on that, there is an accordance between the goals of Indonesia with the implementation of the extradition, MLA, good mutual relations and handing-over to obtain the perpetrators, evidence or assets of the proceeds of crime in the territory of another country.

The implementation of extradition, MLA, good mutual relations and handing-over, it is necessary to obtain justice for perpetrators of crimes in the territory of another country. Based on that, the perpetrators can be processed in accordance with national criminal law of Indonesia in Indonesia, in the sense that the perpetrators receive legal protection from the state nationality. In addition to the criminal offense, the evidence need to be brought in to use the means to support the process of evidence in the trial, as well as the assets of the proceeds of crime which do not usually belong to the perpetrator but belong to other parties, the rights of the suffered needs to get protection, protection is in the form of return of the assets (Asset Recovery) to the owner to use the facility.

Related to extradition, MLA, good relations and handing-over, they need to be regarded as a lesson for the community in general and for government in particular, with regard to the efforts to obtain the perpetrators and evidence or the assets of the proceeds of crime residing in the territory of another country.

Linkage of humanitarian principles to the implementation of extradition, MLA, good relations and handing-over is that it is inappropriate that perpetrators of crimes in the territory of another country are forcely taken away, for example by way of kidnapping in order to be processed in a country that has jurisdiction over it. The reason is that it does not just ignore the human values but also violated the international law, while the relationship with the principle of justice that a criminal offender whose locus delicti is in outside the country could be on trial in the country of his nationality based on the active national principle. It is in order to create justice for perpetrators, that if anyone in any place performs any action (including criminal acts), the state must still protect 
it's citizens. In addition to criminal offender, justice for the victims and the public also need to be restored, i.e. after the perpetrators are through the process of extradition, MLA, good relations and handing-over, and the process is successful, then the state which has jurisdiction upon it can be proceed the law as soon as possible in order to impose sanctions commensurate with his actions, as well as the assets of the proceeds of crime. After the case is handed over to Indonesia, then the assets can be returned to its owner. Article 1 (3) of the Act of 1945 amendment 4 "Indonesia is a country of law." This means by doing all actions, Indonesian State always pay attention to the course of justice, not just based on sheer power. The same thing apply to an effort to get the perpetrator and evidence or assets resulting from criminal acts. Where Indonesia shall observe and implement the legal corridor (international criminal law), by means of extradition, MLA, good mutual relations and handing-over, which means that Indonesia should refer to the principles, norms, and rules applied in the international world.

As it is stated earlier, extradition, MLA, good relations and handing-over are an agreement between two or more states, or it can be said in the form of an international treaty. In this regard Indonesia already provides for international treaties in its constitution, namely Article 11 of Act of 1945. Arrangements regarding international agreements in Indonesia were previously outlined in the Presidential Letter No.2826/ HK/1960 dated August 22, 1960, addressed to the Chairman of the House of Representatives, the president's letter has become a guide in the process of ratification of the treaty, the ratification of the Act legislation or presidential decree, depending on the regulating material. It is from consideration that the international agreement is very urgent because it binds the state in the field a particular field with the subject of another law, namely: states, international organizations, and subjects of international law, it is also from consideration that Article 11 of Act of 1945 is ordered to make the law officers, then on October 23, 2000 there was the Law No. 24 of 2000 on the International Agreement for the creation of legal certainty.

Treaty is created between Indonesia and other international legal subjects, especially with the subject of state law as a realization of the "foreign relations" and "foreign policy (active-free)."
The relation between extradition, MLA, good relations and handing-over with foreign relations is that the four are activities which involves regional and international aspects carried out by the central government. Extradition, MLA, good relations and handing -over are the policies, attitudes and actions taken by the Indonesian government to conduct relations with other countries in order to deal with international issues and to achieve national goals. Indonesia is applied the concept of free and active foreign policy, which means that Indonesia should not be interfered by any party.

Implementation of MLA, Indonesia first signed this kind of agreement with Australia on October 27, 1995 in Jakarta, which was approved by Act 1 of 1999 . Then five years later, on July 24, 2000 in Jakarta, Indonesia signed MLA with China, which was passed by Act 8 of 2006, subsequently on the date of March 30, 2002 in Seoul, Indonesia signed MLA with Korea, which until now has not been ratified. On November 29, 2004 in Kuala Lumpur, Indonesia signed the Treaty of MLA among the eight countries in Southeast Asia hereinafter known as ASEAN $M L A$, one of which includes Indonesia, and the others are Brunei Darussalam, Cambodia, Laos, Malaysia, Philippines, Singapore, and Vietnam. Two other ASEAN countries, Myanmar and Thailand, eventually participated in this ASEAN MLA. The ASEAN MLA countries amount to 10 (ten) countries. ASEAN MLA Agreement is the first experience of Indonesia in joining regional agreements on MLA. Towards ASEAN MLA, Indonesia has also not ratified it, while the countries that have ratified it are Singapore (April 2005), Malaysia (June 2005) and Vietnam.

Unlike the extradition and MLA, good and relationships do not have a concrete form. Until now, there has been no written regulation specifically to this cooperation, even if there are still integrated in the Law on Extradition and the Law MLA. It means the implementation for this still refers to both the law and based on the friendly relations and guided by the national interest and based on the principles of equality, mutual benefit, and take into account national law or applicable international law.

Other means that researchers discuss Handing-Over. Until now Indonesia has not had an arrangement about the Handing-Over. The implementation of the Handing-Over are almost the same with good relationship 
which based on the friendly relations between one country with another in the absence of an agreement. The difference is the Rapport implemented through the centers of power (Depkumham and foreign affairs) while the Handing-Over conducted between the police in one state with those in other states, which are represented by the NCB- Interpol in each country. The setting of Interpol in Indonesia based on the Prime Ministerial Decree dated October 5, 1954 No. 245 / PM / 1954.A decree was appointed as the State Police Service National Central Bureau (NCB), representing the Government of Indonesia. Head of NCBInterpol Indonesia was Chief of Police while the daily executor is the head of the secretariat of the NCB- Interpol Indonesia.

\section{Extradition Process in Transnational Crime}

As it is known, to obtain the perpetrators, evidence, and assets of the proceeds of crime in the territory of another country, the government can use the means that are considered sufficiently well established as recognized by international law and practice. They are extradition, good mutual relations and handing-over to obtain perpetrators, and MLA or good relationships for obtaining evidence and assets of proceeds of the crime. Based on that, the question which may arise is how are the process of extradition, MLA, relationships, and the handing-over? The process of the four means is as the following (Peranginangin, op.cit, 2010: 48):

Extradition Process (Including Relationships), the process of extradition in Indonesia as a requesting state, namely: (a) The application for the search and arrest of Criminal Investigation / Police Ditreskrim to the NCB-Interpol Indonesia; (b) NCB-Interpol Indonesia asked state Interpol to conduct searches and seizures; (c) If the country managed to arrest the sought person, NCBInterpol of Indonesia prepares and submits a request to the Minister of Law and Human Rights for the Indonesian government's extradition request to the State concerned; (d) If the requested state grants the request Extradition, capturing people who will be extradited is done by the staff of NCB-Interpol of Indonesia and the investigator (Crime / Ditreskrim); (e) Arriving in Indonesia, the suspect is handed over to the investigator (Criminal) for processing his case under the Indonesian law; (f) The court's ruling on the person who informed extradited to the countries concerned through diplomatic channels or Interpol channels.

Furthermore, researchers description are as follow First is the pre- extradition: the stage of pre-extradition is one important step, where, the government made efforts to find the whereabouts of the offender. Efforts to find the whereabouts of the perpetrator needs to be done so that there is clarity to which country the government should make a request of extradition. No clarity of information about where the perpetrator is would make government cannot make the requests of extradition to other countries. Even if Indonesia make requests insist to other countries, the request will be rejected because of the absence of the requested (extraditable person).

In order to perform such activity, the government has some information access abroad considered as sufficiently vital, and play as the gate of Indonesia and other countries, namely: NCB-Interpol, ASEANAPOL, Interpol, Liaison Officer (LO) Police, and the Embassy of the Republic of Indonesia (KBRI).

In order to handle the corruption case, Integrated Hunting Team of Suspects and Convicted of Corruption Case should be empowered to look for the perpetrators to their fullest attempts, especially those who went abroad. According to Marwan Effendi (Dir. Prosecution on Jampidsus Attorney General) in one of the paper entitled "Perspectives And Efforts Carried In the Treaty Mutual Assistance Regarding Corruption", the Integrated Team Hunter Suspects and Defendants Case of Corruption (Integrated Team TPK) an Integrated team established by the government to complete the execution and the optimization search suspects and convict corruption cases, both domestically and abroad.

The TPK Integrated Team established by the Decree of the Coordinating Minister for Political, Legal and Security No. Kep-54 / Menko / Politics / 12/2004 dated December 17, 2004 were renewed again by the Decree of the Coordinating Minister for Political, Legal and Security No. Kep-21 / Menko / Politics / 4/2005 dated 18 April 2005. The TPK Joint Team consists of elements of the Coordinating Ministry for Political, Legal and Security, the Attorney General, the Police, the Ministry of Law, Ministry of Foreign Affairs and INTRAC, chaired by the Deputy Attorney General. The case was initially headed Basrief Arief and later replaced by Muchtar Arifin. 
By accessing the network system, the government can ask for help on a whole range of Interpol and the NCB-Interpol throughout the world also to ASEANAPOL members to exchange information when they know the existence of the criminal who was abroad. In addition to access the network system, the government can rely on the Police LO, the current Indonesian government recently put in 6 (six) countries, namely Malaysia, Thailand, Saudi Arabia, Australia, the Philippines, and Timor Leste. In the presence of the Police LO access on the whereabouts of the offender abroad can be more quickly detected because the moves to find the perpetrators is the major concern of these institutions.

KBRI can access information on the whereabouts of the offender abroad. In principle, the KBRI was have a duty to conduct foreign relations with other countries as a government representative in the country concerned in any field, one of which is the field of law enforcement, in this case, the search for the existence of a criminal offender who had fled abroad. The existence of the KBRI in this effort can be observed in the case of Adrian Herling Waworuntu. Initial information of the existence of Adrian in LA was not derived from the NCB-Interpol but from the Consul General in LA which obtained the information from the FBI, and subsequently transferred the informan to the Ministry of Foreign Affairs in Jakarta and the Police Headquarters.

In addition to the connection (exchange of information) with some of the access, the government can release the Red-Notice forwarded to the provisional arrest. Afte $r$ re que sting sta te re ce iv ed confirmation of the existence of the perpetrators and they have been arrested at once detained temporarily by the requested state, requesting state must submit extradition and related documents. The extradition request was conveyed through diplomatic channels that subsequently forwarded to the central authority of each country according to the agreement between the requesting state and the requested state. When it is set in the extradition treaty means aimed at the agency set out in clause extradition treaty, whereas if not in the Extradition Treaty, means must be coordinated with the requested state.

For example in Thailand PEIT, Central Authority is in the Ministry of Internal Affairs of Thailand, while PIEF is Secretary of Justice. The researcher can describe The Extradition requests in the following scheme:

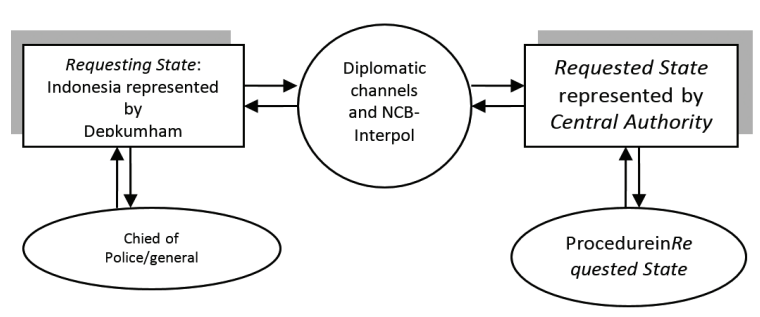

Figure 1. Scheme of Extradition Request

Then if the extradition request is related to people who have not been found guilty / accused (suspects or defendants), extradition requests must be equipped with (Article 8 PEIK): a copy of the warrant of arrest or detention issued by a judge or the competent authorities of the requesting state; a statement that the act which is considered as a crime in a way that gives sufficient reason to suspect that the person sought has committed a crime for which the extradition request addressed.

Whereas if Extradition requests is made on the person who was convicted/convicted (convicts or prisoners), it must be equipped with the Decree of the judge who has had permanent legal force imposed by the court requesting state and a statement that the sentence would be carried out. All documents will be submitted to the requested state in a language of requesting state and/or English and must be equipped with a translation in the language requested state.

With this extradition treaty, the clause is set. If the event of practices and extradition occurred and extradition is granted, the next step is to confirm the pick-extraditable person. Confirmation of the pick-extraditable person must clearly and unequivocally states the day, date, time, and place in which the extraditable person will get picked up and, no less important, the identification and legalization of official requesting state that will pick up, in the sense that the man who picked the extraditable person is the flock of extraditable person pretending to be officials from requesting state. If the extraditable person is not picked up on the specified date, the requested state within a reasonable time, it can liberate extraditable person, and the next extradition requests against the same crime after over reasonable time, the request of extradition may be rejected. So in this condition, besides requesting state must show sincerity in the previous stage, it must also respect the picking of the extraditable person, 
and if there is an obstacle to performing, the picking-up must be confirmed again by the requested state.

The next step of the extradition process is the Post-Extradition, which should be done in it include:(a) The legal process against the extraditable personUnder Article 45 of Law No 1 of 1979 when the extraditable person has been handed over and taken to Indonesia and has been in Indonesia, the extraditable person is submitted to the appropriate authority. In the explanation of the law, it is not found who authorized institution for that, but in our view the competent authority shall be adjusted to the position where the perpetrator will be associated with the legal process. (b) Notice of the results to the requested state. If the extraditable person prosecuted by the requesting state, as is the goal of Extradition, the requesting state must notify in a timely manner to the requested state. Further requested state must also be notified if the extraditable person will be extradited to the third country. In this Extradition Treaty provisions as defined in one of the articles with the name "clause notifications" (in table 3 clause 34). (c) The cases that make use of the means of ExtraditionAccording to information from Budiman Peranginangin (NCB-Interpol Indonesia) in an interview on February 18, 2008, to the current practice of Extradition on the basis of the Extradition Treaty in the case of Indonesia as the requesting state, there are only three (3) full Extradition cases, i.e. in the name Budi, Subagio (BII Pal Merah) and Hendra Rahardja (Bank Harapan Sentosa), those three were extradited from Australia. Furthermore, the practice of Extradition without treaty or Relationships can be observed in the case of Gun Supardi extradited from the United States as described in the conception of Extradition.

\section{Conclusions}

Extradition as a term refers to process in which the basis of treaty or reciprocity (propriety), a country handed over to other countries upon their request, to a person accused or convicted of a crime committed against the law of the country making the request. State requesting extradition has the competence to prosecute the alleged perpetrators of the criminal act.

Rational considerations that determine the law and practice of extradition are the will of all countries to ensure that serious crimes will not be left unpunished. A country whose territory sheltering a criminal often cannot prosecute or punish the perpetrator, only because of the technical rules of criminal law or because it did not have jurisdiction. To close the gap in the international legal argument of "aut dedere aut punire", i.e. the criminal offender shall be punished by a country in which to seek refuge or handed over to countries that can and wants a judgment against him. In addition, the state in which territory of the criminal act happens is the most capable one to prosecute the crime. The evidence that extended widely is available there, and that the country has an interest in the most ground to punish the perpetrators of criminal acts, as well as having facilities to ascertain the truth. Then the most correct and most appropriate state to punish is the territorial state in which the criminal offender who sought refuge to another country and it must consign the criminal offender.

Extradition can also be interpreted as a consignment formally done either based on an extradition treaty existing or based on the principle of reciprocity or relationship, upon a person accused of a crime (the suspect, the defendant, the accused) or someone who has been sentenced to a criminal offense and have binding definite force (inmate, convicted), by the country where he/she resides (requested state) to the state having jurisdiction to try or punish him (requesting state), at the request of the requesting state, with the aim of prosecuting and or execution of the sentence.

\section{References}

Andi Hamzah (1992). Perbandingan Hukum Pidana Beberapa Negara, Sinar Grafika, Jakarta.

C.S.T. Cansil, (1998). Hubungan Diplomatik Republik Indonesia, Balai Pustaka, Jakarta,

I Wayan Parthiana, (1983). Ekstradisi Dalam Hukum Internasional dan Hukum Nasional Indonesia, PT Alumni, Bandung.

I Wayan Parthiana (1987). Beberapa Masalah Dalam Hukum Internasional dan Nasional Indonesia, Binacipta, Bandung,

I Wayan Parthiana, (2003). Pengantar Hukum Internasional, Mandar Maju, Bandung.

I Wayan Parthiana.(2003). Hukum Perjanjian Internasional, Bagian Pertama, Mandar Maju, Bandung.

I Wayan Parthiana (2004). Hukum Pidana 
Internasional dan Ekstradisi, Yrama Widya, Bandung.

I Wa ya n Parthia na, (2004). Hu ku m P e r jn jia n Internasional, Bagian Kedua, Mandar Maju, Bndung.

I Wayan Parthiana (2006). Hukum Pidana Internasional, Yrama Widya, Bandung.

J.G. Starke, Introduction To International Law, Butterworth \& Co, (1989). diterjemahkan dalam bahasa Indonesia oleh Bambang

Iriana Djajaatmadja, (1992). Pengantar Hukum Internasional, Jakarta, Sinar Grafika Offset.

Romli Atmasasmita, (1997). Kapita Selekta Hukum Pidana Internasional, Jilid Kesatu,
CV. Putra A Bardin, Bandung.

Romli Atmasasmita, (2000). Pengantar Hukum Pidana Internasional, Refika Aditama, Bandung.

Romli Atmasasmita, (2000). Perbandingan Hukum Pidana, Mandar Maju, Bandung.

Romli Atmasasmita, (2003). Pengkajian Hukum Tentang OECD Convention On Combating Bri bery of Forei gn Publ $i c$ Offici al s International Busines Transaction, Jakarta, Badan Pembinaan Hukum Nasional Depkumham.

Romli Atmasasmita, (2004). Kapita Selekta Hukum Pidana Internasional, Jilid Kedua, CV. Utomo, Bandung. 